\title{
Sources of New Life Insurance Product Ideas in LIC of India
}

\author{
Furquan Uddin \\ Department of Commerce, Aligarh Muslim University, Aligarh, India
}

\begin{tabular}{|c|c|}
\hline ARTICLE INFO & A B S T R A C T \\
\hline $\begin{array}{l}\text { Keywords: } \\
\text { Actuary, } \\
\text { Competitors, } \\
\text { IRDAI, } \\
\text { LIC of India, } \\
\text { Life Insurance } \\
\text { Kata kunci: } \\
\text { Aktuaria, } \\
\text { pesaing, } \\
\text { IRDAI, } \\
\text { LIC of India, } \\
\text { Asuransi Jiwa }\end{array}$ & $\begin{array}{l}\text { The present complex nature of market has created sturdy challenges } \\
\text { before the business world in the form of designing right product, right } \\
\text { price, right placement and right promotion. In order to survive and } \\
\text { thrive, a marketer has to focus on these challenges. Amongst, right } \\
\text { product is most crucial which requires good and feasible ideas in all } \\
\text { industries including life insurance. In fact, life insurance is perceived as } \\
\text { an unsought and complicated financial product in India. The present } \\
\text { paper is a humble attempt to examine the sources of new life insurance } \\
\text { product ideas in LIC of India. The findings of the present study include } \\
\text { the sources into six groups such as key stakeholders, workforce, orga- } \\
\text { nizational documents and other sources, research unit, competitors, } \\
\text { and national and international source. It may be noticed the key stake- } \\
\text { holders like Insurance Regulatory and Development Authority of India, } \\
\text { actuary, top management, and policyholders play vital role in providing } \\
\text { ideas in the new product development process of LIC of India. }\end{array}$ \\
\hline
\end{tabular}

\section{SARI PATI}

Sifat pasar yang kompleks saat ini menciptakan tantangan kuat bagi dunia bisnis dalam bentuk bagaimana merancang produk yang benar, harga yang tepat, penempatan dan promosi yang tepat. Untuk bertahan hidup dan berkembang, seorang pemasar harus fokus pada tantangantantangan ini. Di antara tantangan itu, menentukan produk yang tepat, adalah yang paling penting, yang membutuhkan ide-ide baik dan layak di semua industri, termasuk asuransi jiwa. Faktanya, asuransi jiwa merupakan produk keuangan yang dianggap rumit dan tak diminati di India. Makalah ini adalah upaya sederhana untuk mengkaji sumbersumber ide produk asuransi jiwa baru di LIC of India. Temuan dari penelitian ini memasukkan sumber-sumber ide ke dalam enam kelompok; pemangku kepentingan utama, tenaga kerja, dokumen organisasi dan sumber lain, unit penelitian, pesaing, dan sumbernasional dan internasional. Ini menandai bahwa para pemangku kepentingan utama seperti Otoritas Aturan dan Pengembangan Asuransi di India, aktuaris, manajemen puncak, dan pemegang kebijakan memainkan peran penting dalam memberikan ide pada proses pengembangan produk baru LIC of India. 


\section{INTRODUCTION}

New product development, a complicated process, is emerged with the organizations' objective/strategy or from an idea that stimulates the process which is constrained free by strategic planning (Kahn, 2001). The former one is a systematic approach to product development that advocates the designing of product development process after setting of objectives and goals, and the latter one may be systematic or unstructured. Both of them have their own significance but the probability of getting success increases with the systematic approach (Kahn, 2001). Besides, the other approaches to product development are market pull and technological push. The first one advocates the marketing philosophy i.e. satisfying consumers needs and wants after scanning the external marketing environment, whereas, the other one is related to idea directed approach to product development (Kahn, 2001).

Ferris et al. (2008) found that having an excellent product development process is an important factor in achieving the consistent, organic, topline growth that companies are seeking today. They emphasised on product idea initiation and generation- sources for new product ideas, product design and pricing, project management/ product implementation process, product IT infrastructure, and product development assessment. In most of the firms, particularly service organization has eight steps viz. idea generation, idea scanning, concept development and testing, marketing strategy development, business analysis, product development/service development, market testing, and commercialization (Rao, 2007).

The new product development process begins with the conception of ideas. The ideas may come from the stakeholders of the organization such as customer, channel members, employees, scientists, engineers, marketing agencies, top management, rivals and others. Frylinck, Michael (2012) elaborates about the steps involved, methodology used, challenges faced, product development process, sources of product ideas like inspiration/creative genious, overseas more mature market, competitors' new products, reinsurers, intermediaries, customer focus groups, gap in existing product range, outdated/ unprofitable/ excessively risky existing products.

From the life insurance perspective, the ideas can be segregated into internal sources as well as external sources. The former one entails actuary, top management, marketer, etc., whereas, the latter one includes policyholders, agents, IRDAI, etc. The idea for variable insurance product has been borrowed from foreign insurance market, and LIC has introduced various ULIPs and variable insurance policies to gain competitive edge by finding the features gap in competitors' products. The ideas behind new trends such as hybrid distribution channel, regulatory trend, difficulty in designing marketing mix, online policy, claim management, customer servicing and FDI and growth have contributed in the development of life insurance market (Barik and Patra, 2014). Kipp and Snook (2008) argued that insurers need to classify health insurance risks as per personal profile and values in order to avoid the health insurance to Indians.

Rao (2006) analysed that by adding value in policies and by minimising the distribution cost and transaction cost the development of present policies could be made successful. Balasubramanyam (2006) mentioned that most significant factor in the determination of premium is the expected rate on investment. Khansili (2004) mentioned about the innovation in product design and pricing by LIC. Generally, innovation in the life insurance market is attributed to initiatives taken by private companies. Private life insurers have joint venture partners from the countries operating in the U.S., U.K., Germany, Canada, Australia, France and South Africa and naturally, the practices of the life insurance market of these countries are reflected in the products being made available in our country by these private 
life insurer. This is reflected in all the products, be it individual life products, unit linked products, universal life products or health products/riders. Gupta and Chuganee (2001) stressed on several steps to be taken by LIC to compete with the new players.

Due to the opening of insurance sector, the public giant LIC faced fierce challenges. Various major decisions are to be taken in regard to products, services, information technology etc. The above analysis of the previous studies reveals that there are few studies related to sources of product ideas, however, there is no any specific study. The present study is unique from past studies as it focuses on the sources of ideas for product development rather than performance appraisal of marketing practices in the field of life insurance. The present research is a case study and specific to LIC of India. The objective of the present study is to examine the sources of life insurance product ideas in LIC of India.

\section{METHODS}

\section{Research Materials}

The present study is exploratory cum descriptive in nature. It makes an effort to gain insights pertaining to sources of product ideas in LIC of India. Judgmental sampling technique has been used to obtain the views of officials of LIC of India. A sample of 150 officials working under the Varanasi Divisional office, LIC of India has been chosen, however, completed questionnaires from 107 respondents have been received. This survey has been conducted during the period of three months i.e. from April, 2017 to June, 2017. The study is based mainly on primary data which have been gathered with the help of structured questionnaire containing different types of questions like dichotomous, multiple choice, scaling and open ended questions.

\section{Research Methods}

The data gathered from different sources have been suitably tabulated, analysed and interpreted with the help of factor analysis using SPSS 17. The data have been tested at 5 percent level of significance through KMO and Barlett's Test to examine the appropriateness of factor analysis for the dataset and checks the overall significance of correlation matrices with the help of examining null hypothesis i.e. "variables are not correlated". Principal Component Analysis has been adopted for determining the total variance explained

\section{RESULTS AND DISCUSSION}

In order to gather the data, officials working under the Divisional office, Varanasi through the different associated branches were contacted. There are 28 branches under the Division office, Varanasi of LIC of India. However, only 9 branches and one Divisional office located in the city of Varanasi were selected to gather the data from the officials. There were different designations of officials, however, from the marketing viewpoint only marketing manager, branch managers, sales managers, administrative officer sales, assistant business manager sales department; assistant manager new business department and development officers
Nature of Research

Type of Data

Instrument Used

Period of the Study

Sampling Area

Sample Size

Sampling Technique

Statistical Tool for Data Analysis

\section{Research Methodology}

Exploratory cum Descriptive

Primary Data

Structured Questionnaire

April, 2017 to June, 2017(Primary)

Varanasi Divisional Office, LIC of India

Approached-150, Received-107

Judgmental Sampling

Factor Analysis 
were targeted. Thus, it is obvious that judgmental sampling was used to gather the data from officials of LIC of India (Table 1).

In order to ascertain the views of LIC officials working under the Divisional office, Varanasi towards the sources of life insurance product ideas, the researcher conducted a survey. For the purpose, sixteen variables were identified. These are policyholders (V1), company past record (V2), employees (V3), agents (V4), competitors' products (V5), competitors' policyholders (V6), research and development (V7), seminar and conferences (V8), trade fair and exhibition (V9), university and government agency (V10), IRDAI (V11), foreign market (V12), actuary (V13), top management (V14), investment department (V15), and accounting department (V16). The responses were rated on five points Likert Scale ranging from unimportant (1) to most important
(5). Factor analysis method has been employed to extract vital information. The factor analysis encompasses KMO \& Bartlett's Test, Principal Component Analysis and naming of resulted factors with concerned variables.

Table 2 shows the result of KMO \& Bartlett's Test. The Kaiser-Meyer-Olkin measure of sampling adequacy is an index used to examine the appropriateness of factor analysis. High values (between 0.5 and 1.0) indicate factor analysis is appropriate and the values below 0.5 imply that factor analysis may not be appropriate. Our calculated KMO values (.773) show that factor analysis is appropriate for the present database. Bartlett's test of Sphericity checks the overall significance of correlation matrices with the help of examining null hypothesis i.e. "variables are not correlated". The calculated value of Bartlett's test (chi-square value 829.578 with degree of

Table 1. Demographic Profile of the Respondents (LIC Officials)

\begin{tabular}{|c|c|c|c|}
\hline Aspects & Items & Number & Percentage \\
\hline \multirow[t]{6}{*}{ Age } & Below 25 years & 6 & 5.61 \\
\hline & 26-35 years & 23 & 21.50 \\
\hline & $36-45$ years & 31 & 28.97 \\
\hline & 46-55years & 33 & 30.84 \\
\hline & Above 56 years & 14 & 13.08 \\
\hline & Total & 107 & 100.00 \\
\hline \multirow[t]{3}{*}{ Gender } & Male & 92 & 85.98 \\
\hline & Female & 15 & 14.02100 .00 \\
\hline & Total & 107 & \\
\hline \multirow[t]{4}{*}{ Educational Qualification } & Graduation & 26 & 24.30 \\
\hline & Post Graduation & 72 & 67.29 \\
\hline & Above Post Graduation & 09 & 08.41 \\
\hline & Total & 107 & 100.00 \\
\hline \multirow[t]{5}{*}{ Experience with LIC } & Up to 5years & 15 & 14.02 \\
\hline & 6-15years & 36 & 33.64 \\
\hline & 16-25years & 41 & 38.32 \\
\hline & More than 25 years & 15 & 14.02 \\
\hline & Total & 107 & 100.00 \\
\hline
\end{tabular}

Source: Questionnaire 
freedom 120 at 5 percent level) was found more than the tabulated value. Hence, the null hypothesis was rejected and it was concluded that the variables are correlated. The above calculation confirms that factor analysis may be applied to analyse the dataset. Further, the Table 3 presents the communalities of variables of the dataset. Communality is the amount of variance of a variable which shows with all other variables being considered. This is also the proportion of variance explained by the common factors.

On the basis of principal component analysis, the variance is explained by the initial the extracted components and rotated components, and the results are displayed in Table 4 . The first section of the table shows the variance explained by the initial solution. It also reveals that there are sixteen possible factors. In order to choose effective factors, the factors with eigen values more than 1 are requested for extracted solution. The second section of the table shows the variance explained by the extracted factors before rotation. The cumulative variability explained by these factors in the extracted solution is about 75 percent, which is similar to the initial solution and thus, no initial solution is lost due to latent factors.

The rightmost section of this table shows the variance explained by the extracted factors after

Table 2. KMO and Barlett's Test

\begin{tabular}{ccc}
\hline \multicolumn{2}{c}{ Kaiser-Meyer-Olkin Measure of Sampling Adequacy } & \multicolumn{1}{c}{.773} \\
\hline Bartlett's Test of Sphericity & Approx. Chi-Square & 829.578 \\
\hline Degree of freedom & 120 \\
\hline Level of Significance & .000 \\
\hline
\end{tabular}

Table 3. Communalities

\begin{tabular}{ccc}
\hline Variables & Initial & Extraction \\
\hline Policy holders (V1) & 1.000 & .783 \\
\hline Company past record (V2) & 1.000 & .609 \\
\hline Employees (V3) & 1.000 & .850 \\
\hline Agents (V4) & 1.000 & .800 \\
\hline Competitors' products (V5) & 1.000 & .806 \\
\hline Competitors' policy holders (V6) & 1.000 & .764 \\
\hline Research and development (V7) & 1.000 & .905 \\
\hline Seminar and conferences (V8) & 1.000 & .874 \\
\hline Trade fair and exhibition (V9) & 1.000 & .802 \\
\hline University and government agency (V10) & 1.000 & .781 \\
\hline IRDAI (V11) & 1.000 & .846 \\
\hline Foreign market (V12) & 1.000 & .704 \\
\hline Actuary (V13) & 1.000 & .442 \\
\hline Top management (V14) & 1.000 & .554 \\
\hline Investment department (V15) & 1.000 & .829 \\
\hline Accounting department (V16) & 1.000 & .625 \\
\hline
\end{tabular}


Table 4. Total Variance Explained

\begin{tabular}{|c|c|c|c|c|c|c|c|c|c|}
\hline \multirow{2}{*}{ Component } & \multicolumn{3}{|c|}{ Initial Eigen values } & \multicolumn{3}{|c|}{$\begin{array}{l}\text { Extraction Sums of Squared } \\
\text { Loadings }\end{array}$} & \multicolumn{3}{|c|}{$\begin{array}{c}\text { Rotation Sums of Squared } \\
\text { Loadings }\end{array}$} \\
\hline & Total & $\begin{array}{c}\% \text { of } \\
\text { Variance }\end{array}$ & $\begin{array}{c}\text { Cumulative } \\
\%\end{array}$ & Total & $\begin{array}{c}\% \text { of } \\
\text { Variance }\end{array}$ & $\begin{array}{c}\text { Cumulative } \\
\%\end{array}$ & Total & $\begin{array}{c}\% \text { of } \\
\text { Variance }\end{array}$ & $\begin{array}{c}\text { Cumulative } \\
\%\end{array}$ \\
\hline Policy holders (V1) & 4.480 & 28.001 & 28.001 & 4.480 & 28.001 & 28.001 & 2.581 & 16.131 & 16.131 \\
\hline Company past record (V2) & 2.170 & 13.559 & 41.560 & 2.170 & 13.559 & 41.560 & 2.257 & 14.105 & 30.236 \\
\hline Employees (V3) & 1.648 & 10.301 & 51.861 & 1.648 & 10.301 & 51.861 & 2.053 & 12.831 & 43.068 \\
\hline Agents (V4) & 1.425 & 8.906 & 60.767 & 1.425 & 8.906 & 60.767 & 1.784 & 11.148 & 54.215 \\
\hline Competitors' products (V5) & 1.159 & 7.247 & 68.014 & 1.159 & 7.247 & 68.014 & 1.751 & 10.943 & 65.158 \\
\hline Competitors' policy holders (V6) & 1.092 & 6.823 & 74.837 & 1.092 & 6.823 & 74.837 & 1.549 & 9.679 & 74.837 \\
\hline Research and development (V7) & .907 & 5.668 & 80.505 & & & & & & \\
\hline Seminar and conferences (V8) & .701 & 4.381 & 84.886 & & & & & & \\
\hline Trade fair and exhibition (V9) & .662 & 4.138 & 89.024 & & & & & & \\
\hline $\begin{array}{c}\text { University and } \\
\text { government agency (V10) }\end{array}$ & .531 & 3.321 & 92.344 & & & & & & \\
\hline IRDAI (V11) & .328 & 2.052 & 94.396 & & & & & & \\
\hline Foreign market (V12) & .299 & 1.867 & 96.264 & & & & & & \\
\hline Actuary (V13) & .216 & 1.347 & 97.611 & & & & & & \\
\hline Top management (V14) & .182 & 1.135 & 98.746 & & & & & & \\
\hline Investment department (V15) & .113 & .703 & 99.449 & & & & & & \\
\hline Accounting department (V16) & .088 & .551 & 100.000 & & & & & & \\
\hline
\end{tabular}

Extraction Method: Principal Component Analysis.

Table 5. Rotated Component Matrix

\begin{tabular}{ccccccc}
\hline Variables & \multicolumn{5}{c}{ Components } \\
\cline { 2 - 7 } Policy holders (V1) & 1 & 2 & 3 & 4 & 5 & 6 \\
\hline Company past record (V2) & .663 & .383 & .073 & .056 & .413 & -.132 \\
\hline Employees (V3) & .232 & .222 & .604 & -.068 & .365 & -.053 \\
\hline Agents (V4) & .025 & .861 & .109 & -.110 & .155 & .243 \\
\hline Competitors' products (V5) & .076 & .799 & .202 & .309 & -.138 & -.026 \\
\hline Competitors' policy holders (V6) & .120 & .006 & .033 & -.074 & .885 & -.049 \\
\hline Research and development (V7) & -.289 & .024 & .013 & .332 & .738 & .159 \\
\hline Seminar and conferences (V8) & .295 & .207 & .069 & .857 & .166 & .094 \\
\hline Trade fair and exhibition (V9) & .011 & .013 & .711 & .494 & -.042 & .025 \\
\hline University and government agency (V10) & -.034 & .287 & .827 & .055 & -.082 & .156 \\
\hline IRDAI (V11) & -.032 & .011 & .304 & -.053 & .045 & .826 \\
\hline Foreign market (V12) & .722 & -.032 & .460 & -.097 & .060 & .314 \\
\hline Actuary (V13) & -.153 & .244 & -.155 & .221 & -.024 & .740 \\
\hline Top management (V14) & .609 & -.076 & -.001 & .028 & -.115 & -.227 \\
\hline Investment department (V15) & .708 & .096 & .009 & .197 & .011 & -.071 \\
\hline Accounting department (V16) & .653 & .380 & -.072 & .479 & -.105 & .111 \\
\hline & .579 & .224 & .316 & .347 & .103 & .095 \\
\hline
\end{tabular}

Extraction Method: Principal Component Analysis.

Rotation Method: Varimax with Kaiser Normalization. 
Table 6. Sources of New Life Insurance Product Ideas in LIC of India

\begin{tabular}{|c|c|c|c|c|c|c|c|}
\hline S. & Factors & & & Sou & & & \\
\hline 1. & $\begin{array}{c}\text { Key } \\
\text { Stakeholders }\end{array}$ & Policy-holders & IRDAI & Actuary & $\begin{array}{c}\text { Top } \\
\text { Management }\end{array}$ & $\begin{array}{l}\text { Investment } \\
\text { Department }\end{array}$ & $\begin{array}{l}\text { Accounting } \\
\text { Department }\end{array}$ \\
\hline 2. & Workforce & Employees & Agents & - & - & - & - \\
\hline 3. & $\begin{array}{l}\text { Organisational } \\
\text { Documents and } \\
\text { other sources }\end{array}$ & $\begin{array}{c}\text { Company Past } \\
\text { Record }\end{array}$ & $\begin{array}{l}\text { Seminars and } \\
\text { Conferences }\end{array}$ & $\begin{array}{c}\text { Trade } \\
\text { Fair and } \\
\text { Exhibition }\end{array}$ & - & - & - \\
\hline 4. & Research Unit & $\begin{array}{l}\text { Research and } \\
\text { Development }\end{array}$ & - & - & - & - & - \\
\hline 5. & Competitors & $\begin{array}{c}\text { Competitors' } \\
\text { Products }\end{array}$ & $\begin{array}{c}\text { Competitors' } \\
\text { Policy-holders }\end{array}$ & - & - & - & - \\
\hline 6. & $\begin{array}{l}\text { National and } \\
\text { International } \\
\text { Source }\end{array}$ & $\begin{array}{c}\text { University and } \\
\text { Government } \\
\text { Agency }\end{array}$ & Foreign Market & - & - & - & - \\
\hline
\end{tabular}

rotation. The rotated factor model makes some small adjustment to all the eight factors. The results of the factor analysis indicate that six factors are considered important in the sources of new product ideas. In order to obtain the variables of each factor, rotated component matrix has been computed with the help of principal component analysis and varimax rotation. The outcome has been shown in Table 5. The criterion for the choosing the variable in one factor is 0.5 or more. Table 6 summarises the sources into six factors. The first factor has been named as 'Key Stakeholders' since all have keen interest and provide ideas in the new product development, viz. "Policyholders (.663)", "IRDAI (.722)", "Actuary (.609)", “Top Management (.708)", "Investment Department (.653)", and "Accounting Department (.579)". "Employees (.861)" and "Agents (.799)" are the workforces of the LIC; therefore, this second factor is named as 'Workforce'. The third factor i.e. 'Organisational Documents and Other sources' encompasses "Company Past Record (.604)", "Seminars and Conferences (.711)", and "Trade Fair and Exhibition (.827)". "Research and Development (.857)" is the 'Research Unit' the fourth factor. "Competitors' Products (.885)" and
"Competitors' Policyholders (.738)" make the fifth factor 'Competitors'. The sixth factor 'National and International Source' entails "University and Government Agency (.826)" and "Foreign Market (.740)".

\section{Discussion}

It has been found in the past studies that the authors have exerted more stress on market share of life insurers, consumer behavior towards insurance policies, rural insurance, customer relationship management, IRDAI, liberalization and globalization in insurance sector. However, few of the studies have thrown light on product development process in life insurance. The present study is distinct from the existing studies as it focuses on root level of product strategy. It is more specific study which reveals the sources of new product ideas that include both internal and external. Frylinck (2012) discussed about the sources of product ideas such as foreign market, customers, intermediaries, competitors' new product, etc. Ferris et al. (2008) also emphasised the significance of sources of product ideas in the product development process and ultimately in the growth and success of the firm. Khansili (2004) 
has advocated the positive impact of foreign market and its collaboration on life insurance product design including product ideas.

\section{MANAGERIAL IMPLICATIONS}

Based on the findings of present study, it can be said that there are number of significant sources of life insurance product ideas. Better product ideas lead to better product developments which ultimately yield increased revenue and market share. Therefore, the present study can be used as consideration of life insurers in designing the new life insurance products.

\section{CONCLUSION}

Thus, it is evident from the analysis that sources of new product ideas are of critical significance for the LIC. It is also obvious from the above discussion that LIC of India has different sources of product ideas in several forms such as IRDAI, Actuary, Marketing Unit, Customers, Employees, etc. however, LIC has to focus more on new sources for creative ideas. As a matter of fact, still a large chunk of the market is deprived of the insurance cover. Perhaps, the lack of simple and benefitting life insurance product may be the strong reason. Even the educated class of the society in India is not able to understand the complexities pertaining to terms and conditions of the life insurance. In order to overcome such a problem and challenge, LIC needs to ponder intensely in designing the products. In regard to product organisation, product development department along with the coordination and cooperation of other departments should continue to develop need based products as per feedback gathered from various sources particularly initiated by marketing people and other stakeholders. The new products should be as per the changing needs of the customer, innovation in the market, and the requirements of different distribution channels of marketing.

REFERENCES

Balasubramanyam, P. A., (2006). Life Insurance Product Pricing- Priorities for Insurer. IRDAI Journal, Hyderabad, September, 13-15.

Barik, Bhagabat and Patra, Rakesh , (2014). Emerging Trends in Insurance- A Study in Indian Life Insurance Industry. Abhinav National Monthly Refereed Journal of Research in Commerce and Management, Abhinav Publication, 36

Feriss, Andy, Kroll, Alice, and Brinkley, Charles, (2008). Key to Success in Life Insurance Product Development. Product Newsletters, Society of Actuaries, June, 71: 22-26 Retrieved from

Frylinck, Michael, (2012). Life Insurance Product Development: A Brief Overview. Retrieved from Documents

Gupta, Arti and Chuganee, Bhakti, (2001). LIC Learns to Tango. Insurance Choronicle, June-July Retrieved from www. icfaipress.org.

Kahn, Kenneth B., (2001). New Product Planning. Response Books Publication, A Division of Sage Pub., New Delhi, 24

Khansili, Dinesh Chandra, (2004). A New Way of Thinking- Innovation in Product Design and Pricing by the LIC. IRDAI Journal, Hyderabad, 11, 6, 25-26.

Kipp, Richard and Snook Thomas, (2008). Designing New Health Insurance Products: Technical Consideration. Insurance Chronicle, The ICFAI University Press, Hyderabad, April, 42-51.

Rao, G.V., (2006). Product Development in Insurance. IRDAI Journal, Hyderabad, August, 14-17.

Rao, K.Rama Mohan Rao, (2007). Services Marketing, Pearson Education, New Delhi, I-impress, 132 